\title{
УДК: 371.68:004.9
}

Савченко Зоя В'ячеславівна, науковий співробітник Інституту інформаційних технологій і засобів навчання АПН України

\section{СТАН РОЗРОБКИ ПРОГРАМНОГО ЗАБЕЗПЕЧЕННЯ ТА ІНФОРМАЦЙНИХ БАЗ ДАНИХ ДЛЯ НАВЧАЛЬНИХ ЗАКЛАДІВ}

\section{Анотація}

Стаття присвячена актуальним питанням сучасного стану розробок комп'ютерних засобів навчання та інформаційних баз даних навчально-педагогічних комп’ютерних програм, способам поінформованості та розповсюдження їх у навчальних закладах освіти, а також висвітлення досвіду розробок Російської Федерації в аналогічних питаннях.

Ключові слова: інформаційні бази даних, комп’ютерні програмні засоби навчання, загальноосвітній навчальний заклад.

Одним із пріоритетних напрямків реформування освіти на сучасному етапі $є$ використання інформаційних технологій (IT), навчально-педагогічних комп’ютерних програм (НПКП), мультимедійних засобів навчання у навчально-виховному процесі сучасного освітнього закладу $[1,2]$.

Ефективна інтеграція IT в навчально-виховному процесі вимагає дотримання чіткого балансу між кращими методами традиційного навчання та виховання в освітніх закладах із доцільністю використання нових можливостей такого процесу інтеграції. Завдяки розвитку нових технологій відбувається поступовий перехід загальної середньої освіти на якісно новий рівень, який забезпечується насамперед новими методами та засобами навчання. Інформаційні технології впливають на всі компоненти системи навчання: мету, зміст, методи та організаційні форми навчання. Сучасні засоби навчання дозволяють розв’язувати складні та актуальні завдання педагогіки, а саме: розвиток інтелектуального, творчого потенціалу, аналітичного мислення та самостійності учня [3].

Метою статті $\epsilon$ огляд та аналіз сучасного стану комп'ютерних засобів навчання, існуючих вітчизняних та зарубіжних (російських) комп’ютерних розробок програмного забезпечення, які впроваджуються в навчальних закладах освіти, наявності інформаційних баз даних навчально-педагогічних комп'ютерних програм та визначення необхідних вимог до них. 
Широке впровадження прикладного програмного забезпечення (ППЗ) та комп'ютерних технологій у навчально-виховному процесі освітніх закладів, передбачає використання нових педагогічних технологій, форм і методів навчання, електронних підручників та навчальних комп’ютерних програм (НКП).

На теперішній час накопичено певний успішний досвід практичного використання НКП та комп'ютерних технологій для супроводу вчителями навчального процесу на уроках у школі. Це переконливо свідчить про незаперечні переваги раціонального поєднання традиційних методичних систем навчання 3 інформаційними технологіями та створення на основі такого поєднання новітніх інформаційних технологій навчання — вагомих складових комп’ютерно-орієнтованих дидактичних систем.

На ринку України наявний досить великий перелік різних типів педагогічних програмних засобів, призначених для супроводу навчально-вихованого процесу в освітніх закладах. Більшість програмних засобів є електронними версіями друкованих підручників,дещо доповнених та більш зручних з погляду можливості пошуку в них інформації. Але останнім часом з'являється все більше педагогічних програмних засобів, які мають не лише інформаційне наповнення, але й забезпечують взаємодію користувача 3 програмою та роботу в діалоговому режимі. Сучасні педагогічні програмні засоби навчання дозволяють користувачеві самостійно моделювати різні процеси, проводити досліди та здійснювати контроль засвоєння матеріалу за допомогою тестування. Так, наприклад, програми з історії містять не лише тексти підручника, а й історичні карти, біографії видатних осіб, хронологічні переліки і навіть відеофрагменти. Електронні атласи, окрім карт, мають тексти, що коментують i доповнюють інформацію, подану на картах, запитання для самоперевірки, ілюстрації і навіть ігри на основі карт атласів. Багато підручників з фізики та хімії дозволяють, окрім вивчення матеріалів курсу, проводити лабораторні роботи, демонстрації, досліди та тестування. Мовні програми також мають режими навчання, практики та тестування. Біологічні підручники мають у своєму складі, окрім текстів, ілюстрації, рухомі моделі об'єктів, тестові завдання. Підручники з математикиі дозволяють створювати та розв'язувати рівняння і задачі, будувати графіки. Електронні підручники з інформатики містять навчальні та довідникові посібники, середовища програмування та демонстрації [4]. Отже, можна зробити висновок про 
багатоплановість та різноманітність можливостей сучасних педагогічних програмних засобів навчання.

3 метою забезпечення рівного доступу до якісної освіти і впровадження інформаційних технологій у навчально-виховний процес освітніх закладів, підвищення рівня підготовки вчителя до використання інноваційних технологій, відповідно до Положення про проведення апробації електронних засобів навчального призначення, затвердженого наказом МОН Україні від 02.06.2004 р. [5], кожного навчального року проводяться апробації нових розробок електронних засобів навчального призначення у загальноосвітніх, професійно-технічних, вищих педагогічних навчальних закладах та інститутах післядипломної освіти педагогічних кадрів. Перелік таких нових розробок НКП подається МОН України до початку кожного навчального року, а після завершення апробацій подаються рекомендації та зауваження щодо якості та відповідності апробованих розробок вимогам та стандартам до них. Такий спосіб поінформованості та розповсюдження нових розробок НКП дає змогу педагогам освітніх закладів використовувати у своїй практичній діяльності найактуальніші та якісні програми навчально-виховного призначення.

В інший спосіб про наявність комп'ютерних програмних засобів та спосіб їх отримання, можна дізнатися в Інтернеті на сайтах розробників та розповсюджувачів цих програм. За наказом МОН України було проведено реєстрацію усіх розробників та розповсюджувачів КПЗ, реєстр яких нараховує біля 500 показників станом на 2007 рік.

Великий перелік КП пропонує сайт “Острів знань” [6]. Тут викладені програмні засоби для різних класів та 3 усіх навчальних предметів загальноосвітніх шкіл. Наведений приклад (тільки для початкової школи) свідчить про достатньо широкий обсяг та доступність таких навчальних розробок. Звертаючись до посилань 3 кожного 3 предметів, користувач може отримати інформацію про наявність розробок із певного предмету, «шпаргалки», що допомагають школярам виконувати завдання вдома, додаткові матеріали, розробки уроків, програми тощо. Але не кожен предмет має змістовне наповнення (наприклад, природознавство).

. Українська мова 1-4 клас

- $\underline{\text { Читання }}$

- Математика 1-4 клас 
. Російська мова 1-4 клас

- І пноземні мови

- $\underline{\text { Я і Україна }}$

- Музика 1-4 клас

- Образотворче мистецтво 1-4 клас

- Природознавство 1-4 клас

- Трудове навчання 1-4 клас

- Основи здоров'я 1-4 клас

- Організація безпеки життя

- Фізична культура 1-4 клас

Цікавим прикладом щодо впровадження в освітні заклади є діагностичнопроектуючий комп'ютерний комплекс “Універсал-03.28”. Він має великий банк даних комп'ютерних програмних засобів 31 по 12 класи, майже 3 усіх предметів за навчально-виховною програмою освітнього закладу. Банк файлів "Універсал" працює в режимі поповнення та розповсюджується через сайт розробника [7]. Комп'ютерний комплекс «Універсал» експериментально апробований на всеукраїнському i регіональних рівнях (наказ Міністерства освіти і науки від 28.09.2001 р. №665) в 116 навчальних закладах України. Цей програмно комп'ютерний комплекс (ПКК), рекомендований МОН України (наказ МОН України від 06.07.07 p №580) до широкого використання в загальноосвітніх навчальних закладах за умови спеціальної підготовки педагогів та практичних психологів до роботи за новою виховною системою «Психолого-педагогічне проектування соціального розвитку учнів загальноосвітніх навчальних закладів». На рис. 1 наводиться приклад доступу до розробок навчальних програм.

Зміст:

01). Словник програми "Універсал";

2). Банк навчальних програм;

3). Банк навчально-виховних програм;

4). Банк модулів навчально-виховного процесу;

5). Файл змін в регістрі настройки шрифтів в програмі "Універсал" під операційну систему WINDOWS XP;

06). ФОТО архів програми "Універсал";

07). FAQ (часто задані запитання);

O8). IHШE.

(1) Словник програми "Універсал". Скачати? (15кБ!*,rar!)

(2) Банк навчальних програм:

Рис.1. Приклад доступу до розробок навчальних програм. 
(2) Банк навчальних програм Діагностично-проектуючого комп'ютерного комплексу “Універсал-03.28” містить приблизно 150 комп'ютерних програмних розробок [8].

Перелік електронних засобів навчального і загального призначення, створених Компанією “Дієз-продукт” та рекомендованих Міністерством освіти і науки України для використання у загальноосвітніх навчальних закладах (Лист МОН України від 21.08.2007 № 1/9-482), пропонується в Інформаційному збірнику Міністерства освіти і науки України 26-27 (вересень 2007), на який можна підписатися та отримувати інформаційну розсилку продукції цієї компанії. У кожному номері розсилки Компанія "Дієз-продукт" пропонує огляд програмного забезпечення для шкіл (включаючи і безкоштовні програми), корисні поради щодо інформатизації освітнього середовища навчального закладу, відповіді на запитання i ще багато цікавої та потрібної інформації [9].

Важливим способом розповсюдження НКП серед освітніх закладів (особливо сільських та тих, що не мають Інтернет-мережі), $є$ придбання компакт-дисків на ринках або отримання їх приватним шляхом від розповсюджувачів чи розробників цих КП, як наприклад від розробника ЗАТ “Мальва". Але придбання КП в такий спосіб є малоефективним та несанкціонована продукція не завжди відповідає якості та науковим стандартам НКП.

Враховуючи такий широкий аспект розробок КП та способи їх розповсюдження, можливості ЗНЗ у виборі та придбанні КП, які б задовольняли діючі санітарно-гігієнічні, психофізіологічні та інші вимоги, $є$ не простими та можуть виявитися малоефективними.

Нині виникло нагальне питання про централізований збір даних наявності всієї видавничої продукції розробок КП та систематизації їх за типами, напрямками використання, предметами та іншими показниками. Створенням таких інформаційних баз даних стали займатися в багатьох навчальних закладах та установах освіти. Прикладом такої діяльності може бути створена особиста база даних ЗОШ I-III ступенів №13 м. Ірпеня, для створення власного інформаційного середовища школи та бази даних НКП [10].

Головним інформаційно-обчислювальним центром Міністерства освіти і науки України, було розроблено локальну базу даних (за тематикою “Моделі та засоби 
розробки програмного та інформаційного забезпечення з навчальних предметів для загальноосвітніх навчальних закладів” під керівництвом А.М. Гуржія, академіка АПН України, д т. н. та професора В.В. Гапон). Під час виконання робіт за темою "Програмне забезпечення та інформаційна база даних підручників та навчальних посібників" було проведено класифікацію видавничої продукції, створено інформаційну базу даних та розроблено програмне забезпечення. Основними об'єктами інформаційної бази даних були визначені номер видання, автор, мова видання, назва, рік видання та кількість сторінок, класи, для яких призначене видання, навчальні предмети, тип публікації, видавництво, ступінь школи, ступінь початкової школи, категорія видання, анотація або текст навчальної програми. За підсумками заповнення інформаційної бази даних виявилося: підручників - 337 , навчальних програм - 128, навчальних посібників - 270, зошитів - 72, навчальнонаочних посібників - 31, навчально-методичних посібників - 30, словників - 18 та ін. Аналізуючи стан існуючих інформаційних баз даних (БД) програмного забезпечення, слід зауважити, що під час проектування системи таких інформаційних БД були виділені об'єкти, задані їхні характеристики та встановлені структурні зв'язки між об'єктами. Головними об'єктами системи були виділені: предмети та курси, базовий навчальний план, типовий навчальний план, типи загальноосвітніх навчальних закладів, ступені навчання, класи, навчальні програми, орієнтовані поурочні планування уроків, календарні плани вчителя. Програмне забезпечення автоматизованої системи реалізовано в середовищі Microsoft Office Accsess97 [3].

Проводячи дослідження 3 питання інформаційного забезпечення та розповсюдження розробок НКП, нами була створена та наповнена експериментальна база даних НКП, розроблених для загальноосвітніх навчальних закладів та схвалених Науково-методичною комісією засобів навчання та шкільного обладнання 3 питань МОН України, що мають Гриф МОН України. [11]

До переліку такої БД увійшли більше 150 розробок, які виконані на замовлення та кошти держави чи недержавних організацій. База сформована у табличній формі MSO Excel 2003 (табл. 1), у якій показниками полів вибрані такі характеристики: назва КП, тип КП (ППЗ, ПМК, НПК та ін.), види діяльності (навчально-виховна, управління), предмети, класи (з 1 по 11), анотація, тип навчального закладу (ЗНЗ, ВНЗ, ПТУ), розробник та адреса (поштова та електронна), дозвіл МОНУ 
(рекомендовано чи схвалено), рік та № листа отримання Грифу МОН України, за які кошти розроблена КП та джерело інформація (можливість отримати КП) [11].

Використовуючи цю БД, було проаналізовано КП за типами програм, предметами, фірмами-розробниками та іншими показниками. Систематизація БД та дослідження існуючих КП показали, що існують назви таких типів програм, які найчастіше вживаються: комп'ютерний навчальний комплекс, мультимедійна навчально-ігрова програма, віртуальна лабораторія, відеофільм, електронний навчально-методичний комплекс, аналітично-пошукова система, майстер-клас, програмно-методичний комплекс, педагогічний програмний засіб, навчальний програмний комплекс, навчальний посібник, програмне середовище, енциклопедія, електронний посібник, електронні навчальні курси, електронні атласи, електронні енциклопедії, інтегровані електронні комплекси, бази знань, і це ще неповний список назв типів програм які постійно поповнюється все новими назвами. На жаль, такий широкий перелік назв типів розробок КПЗ, не обумовлений чіткою визначеністю в термінології призначень цієї продукції. 


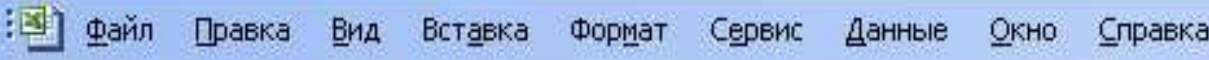

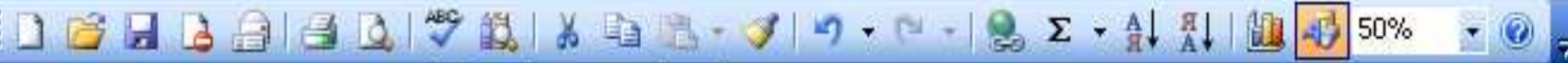

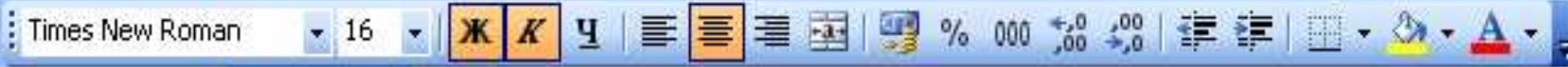

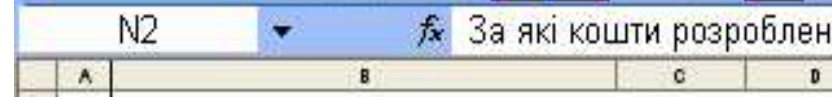

Комп'югерні програми для загальноосвітніх навчальних закладів.

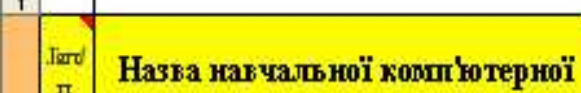
Iрограмп

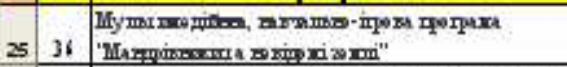

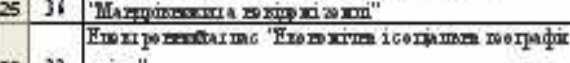

32 cxiry

27.35 cairy"

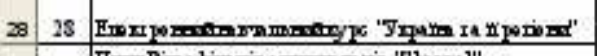
29.4

Frox

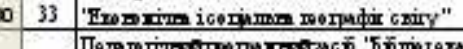

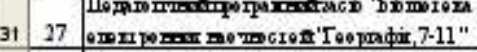

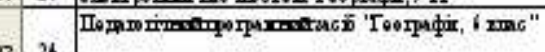

24

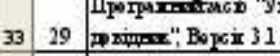

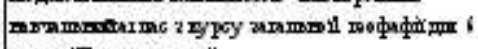

Macy "Hama maxis"

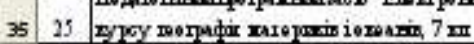

По

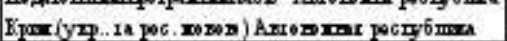

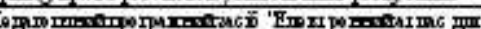

3731 (1)

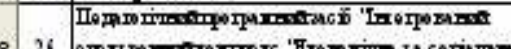

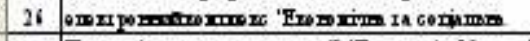

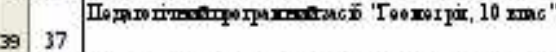

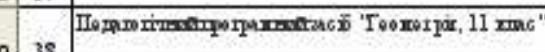

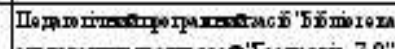

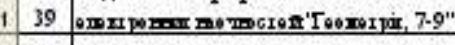

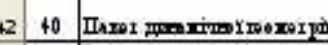

药 41 Imas"

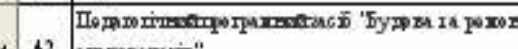

12

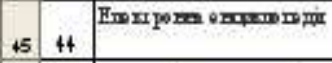

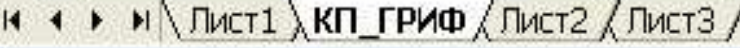

\begin{tabular}{|c|c|c|c|}
\hline 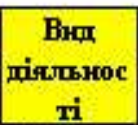 & Предтет & Клас & Aнoтаuif \\
\hline HADT mII & roerpugir & & \\
\hline Hasp anI & Ixerpughir & $10-11$ & 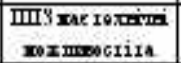 \\
\hline Hast mil & merpafix & & \\
\hline Has? & meorgandiz & & 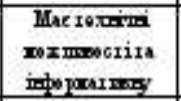 \\
\hline HADT MIII & Ioergaghir & & \\
\hline Удийіx & Toerpugfir & & 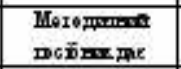 \\
\hline Haxp anI & roorpuquit & 7-11 & \\
\hline Hagr max & roorpugir & 6 & \\
\hline HAOP MII & morrygin & & \\
\hline Haxp anI & morgangir & 1 & \\
\hline Haspasix & I0erpengir & 7 & $\begin{array}{l}\text { Whe m mori } \\
\text { dopayzam }\end{array}$ \\
\hline HAOP MII & roerpugir & & \\
\hline HAOP. III & roorpugir & & \\
\hline HAOP DII & I0erpaghir & 10 & 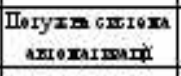 \\
\hline HaDrasir & moxorpix & 10 & \\
\hline Hasp anI & moXoryir & 11 & \\
\hline Haxpmax & roor I0I pir & $7-9$ & \\
\hline Hagr anI & moxorpir & $7-9$ & $\begin{array}{c}\text { HoIa- manIII } \\
\text { mox maxicis }\end{array}$ \\
\hline Has? MII & 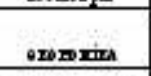 & 10 & 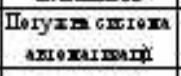 \\
\hline HASP BII & 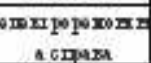 & & \\
\hline Hagr anI & 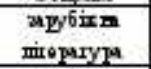 & & \\
\hline
\end{tabular}

\begin{tabular}{|c|c|}
\hline 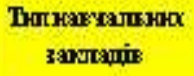 & POЗ OОЕНН \\
\hline Mr. mor axI & DIII "AдmRin" \\
\hline MI. mox anII & 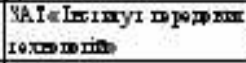 \\
\hline MI. ADS anI & 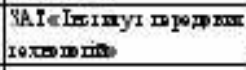 \\
\hline MI. MSI anII & 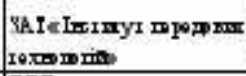 \\
\hline MI. ngI uII & 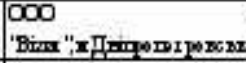 \\
\hline ar. mox anII & YAI 'Mamsas" \\
\hline MI. mor MXII & YAI 'Whmaxa" \\
\hline anIII & 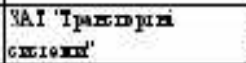 \\
\hline ar. max anII & 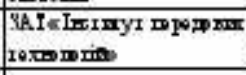 \\
\hline MI. mox axII & 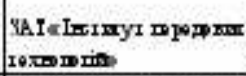 \\
\hline $\mathrm{ar} . \mathrm{mox}$ anxII & 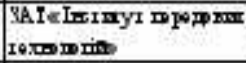 \\
\hline ar. mox aII & 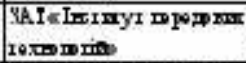 \\
\hline Mr. mox uIII & 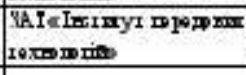 \\
\hline ar. mox anII & IOB "ABI 표 \\
\hline Mr. mox axI & SAI 'Mammas" \\
\hline Mr nor MIII & YAT 'Mnmsa" \\
\hline MI. mox MIII & YAI 'Mnmmsa" \\
\hline ar. mox ant & 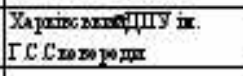 \\
\hline ar.m & IOB " $\mathrm{ABI}$ 푬" \\
\hline 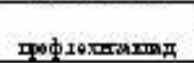 & $\mathrm{AI}$ «CWII \\
\hline m & \begin{tabular}{|l|}
000 \\
"Bimax":
\end{tabular} \\
\hline
\end{tabular}

\begin{tabular}{|c|c|c|c|c|}
\hline $\begin{array}{c}\text { Ampeca } \\
\text { розробника }\end{array}$ & $\begin{array}{l}\text { Дозвіл } \\
\text { Мону }\end{array}$ & Pix & $\begin{array}{c}\text { Ho } \\
\text { rucma } \\
\text { doreanu }\end{array}$ & 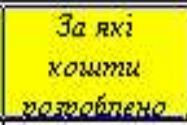 \\
\hline 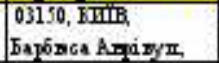 & 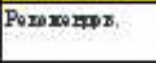 & 2006 & $\begin{array}{c}111206 \\
361111-7232\end{array}$ & 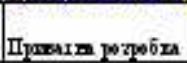 \\
\hline 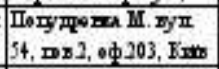 & Poxo xompy. & 2005 & $\begin{array}{l}150205 \\
3.111-64\end{array}$ & 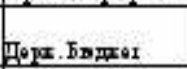 \\
\hline 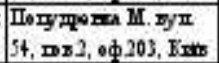 & Crantos & 2005 & \begin{tabular}{|c|}
1611.05 \\
N:1/11-6153
\end{tabular} & 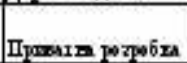 \\
\hline 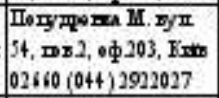 & 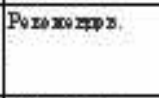 & 2002 & $\begin{array}{c}291202, \\
\text { J } 11111-4383\end{array}$ & 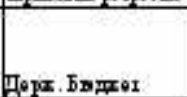 \\
\hline 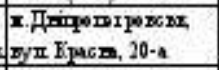 & 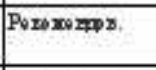 & 2005 & $\begin{array}{c}050505 \\
\text { No1 } 111-2104 \\
\end{array}$ & 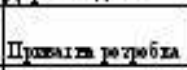 \\
\hline 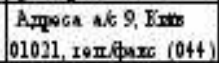 & 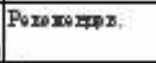 & 2005 & $\begin{array}{c}040505 \\
\text { 341111-2154 }\end{array}$ & 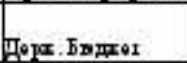 \\
\hline 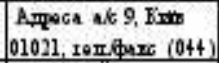 & 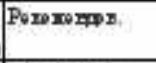 & 2006 & & 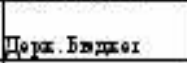 \\
\hline 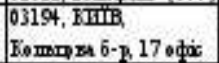 & POX0X0 & 2006 & & पөрx. \\
\hline 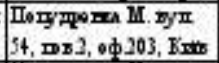 & 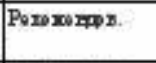 & 2004 & & $3706 \mathrm{xa}$ \\
\hline 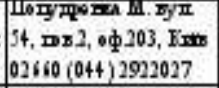 & 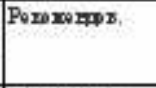 & 2005 & $\begin{array}{r}040505 \\
\text { WFil1121-21S3 }\end{array}$ & 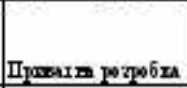 \\
\hline 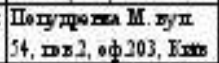 & PoroxompDx. & 2002 & $\begin{array}{c}2912.02,1 / 11 \\
438+\end{array}$ & 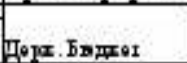 \\
\hline 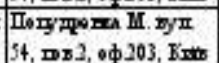 & 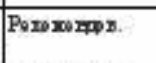 & 2004 & $\begin{array}{l}290604 . \\
3 \mathrm{H}+43\end{array}$ & 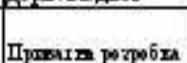 \\
\hline 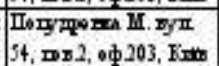 & 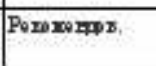 & 2004 & $\begin{array}{l}3012.04, \\
341050\end{array}$ & 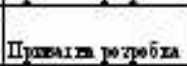 \\
\hline 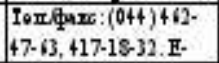 & 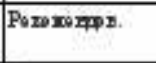 & 2005 & $\begin{array}{l}150205 \\
N=1111-61\end{array}$ & पеx \\
\hline 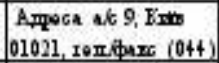 & 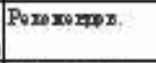 & 2006 & & 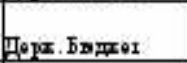 \\
\hline 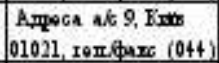 & 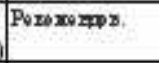 & 2006 & & 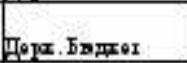 \\
\hline 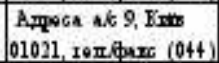 & 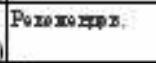 & 2006 & & 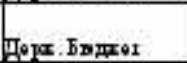 \\
\hline ilis, I.Xapum & 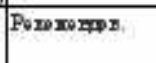 & 2002 & & 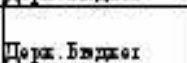 \\
\hline 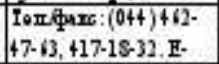 & Poroxomp & 2005 & $\begin{array}{l}150205 \\
N=1111-61\end{array}$ & पूp: \\
\hline 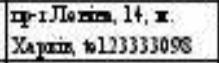 & 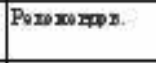 & 2006 & & 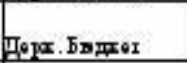 \\
\hline 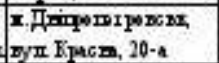 & Crontwas & 2005 & \begin{tabular}{|c|}
1611.05 \\
No1/11-66336
\end{tabular} & 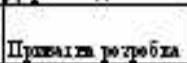 \\
\hline
\end{tabular}

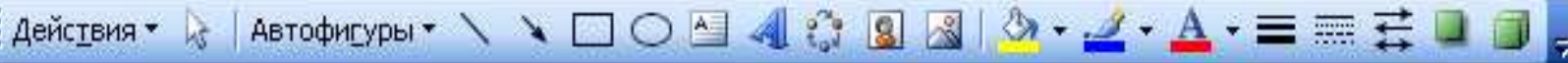


Для того щоб допомогти споживачам розробок, у першу чергу викладачам вищих навчальних закладів та вчителям середніх шкіл, орієнтуватися в цьому різноманітті списку типів КЗН, необхідно провести систематизацію, чітке визначення термінології кожної із типів розробок та донести до відома широкому загалу розробників цієї продукції.

Специфіка такої галузі, як освіта, поряд з ефективністю викладання має на меті високий ступінь відповідальності за наслідки застосування тих або інших засобів навчання. Саме із цієї причини комп'ютерні засоби навчання повинні мати високу якість розробок, повинні оцінюватися з урахуванням фактору безпеки, дотримання санітарно-гігієнічних норм, методичних, психолого-педагогічних та інших аспектів упровадження програмно-методичних комплексів у закладах освіти. На нашу думку, перш ніж такі КПЗ будуть використовуватися в навчальному закладі, вони повинні пройти такі етапи досліджень та випробувань:

- оформлення документації на присвоєння рекомендаційного грифу МОНУ та дотримання вимоги, на підставі інструкції про порядок розгляду й затвердження грифу на навчальні електронні видання, де термін дії грифу на електронні видання у зв'язку з комп'ютерною технікою, що швидко змінюється, - 2 роки. Після закінчення даного терміну необхідно відновити подання документів на одержання рекомендаційного грифу;

- неухильне дотримання всіх вимог державної науково-технічної експертизи з присвоєння рекомендаційного грифу, які ставляться до комп'ютерних навчальних програм;

- організація на чолі МОНУ єдиного централізованого Фонду навчальних комп'ютерних програм, електронних посібників та інноваційних розробок; заснування Експертної ради 3 усіх ключових питань проходження та розробок таких програм від реєстрації, апробації до права на отримання Грифу сертифікації та розміщення такого програмного продукту в Фонд НКП.

Дослідження зарубіжних джерел у питаннях стану розробок НКП та КПЗ показали, що незважаючи на стрімкий розвиток інформаційних технологій (насамперед multimedia, Internet) та впровадження в навчальних закладах комп'ютерних навчальних програм для інформатизації різних видів діяльності в 
системі освіти, забезпечення якості й ефективності навчальних програм, які розроблюються, залишається на низькому рівні [12]. Наприклад, за даними американських фахівців, понад $80 \%$ навчальних програм не задовольняють педагогічні вимоги. За іншим даними, як свідчать закордонні та вітчизняні педагогічні дослідження, 90\% програмних засобів навчання $є$ непридатними для використання у навчально-виховному процесі у зв'язку з невідповідністю психологопедагогічним та іншим вимогам. Слід зазначити низьку якість навчальних програмних продуктів, розроблених різними комерційними фірмами. Так, у Німеччині, наприклад, 34000 програмних засобів тільки 80, тобто тільки 2\% відповідають мінімальним критеріям якості. Так за даними РФ, із 30 комп'ютерних навчальних програм (програмно-методичних комплексів), поданих на засідання Експертної ради РОСФОКОМП, близько 20 програм представлено на подальшу оцінку якості, iз них 8 програм були рекомендовані для подальшої експертизи, які біля 50\% (із вказаних 8) задовольнили вимоги, що пройшли експертизу та отримали право на використання в навчальних закладах.

На підставі проведених досліджень можна стверджувати, що найбільш адаптованим до нашої системи освіти є досвід розробок комп'ютерних засобів навчання, організації питання поінформованості та розповсюдження ринку КЗН в освітніх закладах Російської Федерації. На підставі положення Російського фонду комп'ютерних навчальних програм (РОСФОКОМП, М, 1997), комп'ютерними навчальними програмами (КНП) є: комп'ютерні підручники, самовчителі, посібники, довідники, словники, і прикладні навчальні, контролюючі програми, тести та навчальні ігри. КНП $є$ електронним засобом навчання, вони включені в РОСФОКОМП, занесені до електронного каталогу фонду засобів НІТ бібліотеки МГУ та мають статус публікації.

Питання про положення та вимоги, про сертифікацію КНП та електронних видань у РФ, за тематикою даної статті не розглядаються, хоча питання є дуже актуальними і важливими для стану вітчизняних розробок.

Зазначимо лише, що надалі розглядаються тільки сертифіковані програмні засоби навчання, так як тільки така продукція може відповідати на питання практичного плану: як вибрати програмний продукт? як використати його iз традиційною формою навчання? які підручники, методичні посібники, книги йдуть у 
комплекті із програмою? чи відповідає програмно-методичний комплекс існуючій навчальній програмі? і т. д. Сертифікація дозволяє відповісти на ці питання, виділяючи серед безлічі програмних засобів, що мають обіг на програмному ринку, програми із сертифікатом Міністерства освіти РФ і тільки така продукція пропонується до впровадження у ЗН3 та занесена до Російського фонду комп'ютерних навчальних програм (Росфокомп), який існує при Інституті інформатизації освіти (ІнІнфо) 3 березня 1993 року та $є$ галузевим фондом програмних засобів навчального призначення (ПЗ НП) у системі освіти.

Одночасно система освіти інформується за допомогою інформаційних органів та інформаційних мереж про програмні засоби, які отримали сертифікат Міністерства освіти РФ, і про ті ПЗ НП, яким у присвоєнні сертифікату відмовлено. Інформуючи споживачів про якість програмного продукту, Міністерство освіти здійснює, таким чином, державну політику у галузі інформатизації освіти, сприяючи впровадженню нових високоякісних інформаційних технологій в освіті та підвищуючи ефективність і значимість новітніх технологій в навчальних закладах освіти. На продукції, яка розповсюджується для широкого загалу користувачів, зазначається: “...здобуваючи програмний продукт, поцікавтеся, чи є на нього сертифікат Міністерства освіти. Переконайтеся також у наявності знаку відповідності на обкладинці документації та етикетці дискети чи СД. Інститут інформатизації освіти й Російський фонд комп'ютерних навчальних програм готові розглядати рекламації на сертифіковану ними програмну продукцію. Тільки спільними зусиллями ми зможемо закрити шлях у російську школу низькосортним програмним виробам.” [13].

Як уже зазначалося, Російський фонд комп'ютерних навчальних програм існує 3 1997 року. Він складається з інформаційної та програмної частини системи фонду:

- Інформаційно-довідкова система "РОСФОКОМП" (ІДС "РОСФОКОМП") є банком даних, що містить інформацію про 1800 програмних засобів навчального призначення (станом на 1997 рік, а в 2007 році біля 50 000);

- система реєстрації програмних засобів навчального призначення.

ІДС "РОСФОКОМП" широко використовується для одержання інформації про програми та для підбору конкретних навчальних засобів згідно заявкам відвідувачів РОСФОКОМП - представників навчальних закладів і приватних осіб. Починаючи 3 
1992 р., РОСФОКОМП регулярно видає каталог "Комп'ютерні навчальні програми", а з 1996 р. каталог "Комп'ютерні навчальні програми та інновації" можна придбати через підписку на звітний рік, а також каталог подається в електронному вигляді.

В електронному каталозі "Комп'ютерні навчальні програми та інновації“ за 2007 рік подається електронна таблиця в системі MSO Excel, файл Elektr KatalogPPZ.exl, в якій подано біля 8000 електронних посібників навчального призначення.

У цій БД показниками полів вибрані такі характеристики як: назва КП, предмет, напрямок, анотація, класи-вік (дошкільна, початкова, основна, старша школи та абітурієнти); розробник; електронні адреси розповсюдження.

Наведемо приклад подання такої обширної інформації із БД за одним із предметів - хімія, за електронною адресою [14].

Подаються матеріали з хімії з електронної бібліотеки сайту "Chemnet", які $\epsilon$ фондом публікацій, підготовлених для інформаційного забезпечення навчальних курсів із хімії для студентів та аспірантів хімічного чи інших факультетів ВНЗів, а також абітурієнтів та учнів середньої школи.

\section{"Учебные базы данных"}

- База данных Ивтантермо

- Банк данных РАДЭН (радиационные и энергетические параметры двухатомных молекул)

- Электронное издание справочника "Константы двухатомных молекул"

- Окислительно-восстановительные потенциалы

- База данных "Термические константы веществ"

- "Химический ускоритель". Справочно-информационная система.

- Физические и химические постоянные:

- водорода и его соединений

- азота и его соединений

- элементов 1 группы и их соединений

- элементов 2 группы и их соединений

- элементов 3 группы и их соединений

- элементов 4 группы и их соединений и до 7 групи включно

- переходных металлов 4 периода и их соединений

- переходных металлов 5, 6 периодов и их соединений

- благородных металлов и их соединений

- лантаноидов и их соединений

- актиноидов и их соединений

- Стандартные термодинамические свойства химических веществ:

- на основе элементов I и II групп

- на основе элементов III и IV групп

- на основе элементов V и VI групп и VII 

абитуриентов

- Учебные материалы к школьному курсу химии

- Задачи для подготовки к вступительным экзаменам на химический фак-тет МГУ

- Электронные учебники

- Г.В. Прохорова (Химфрак МГУ) Качественный химический анализ

(практикум для школьников)

- А.В. Мануйлов, В.И.Родионов (г. Новосибирск) Основы химии

- Г.И. Дерябина,Г.В. Кантария (г.Самара) Органическая химия

○ Л.Н. Мишенина (г.Томск) Неорганическая химия

- С.Т.Жуков Экспериментальный учебник по химии для 8-го и 9-го классов для 10-го и 11-го классов

- Задачи химических олимпиад

- Всероссийские олимпиады школьников по химии

- Международные олимпиады

- Международная Менделеевская олимпиада по химии

○ В.А.Сорокин, В.В.Загорский, И.В.Свитанько Задачи химических олимпиав

\section{Мультимедиа публикации}

- Учебные видеоматериалы к курсу общей и неорганической химии для нехимических специальностей

- Лабораторная работа "Сканирующая зондовая микроскопия блоксополимеров" (описание работы с элементами мультимедиа и интерактивности)

- Серия 3D иллюстраций "Взгляд B Наномир"

- Интерактивные трехмерные модели молекул для школьного курса химии

- Видеозапись наблюдения колебательной кинетики каталитического окисления $\mathrm{H}_{2}$ и $\mathrm{CO}_{\text {на }}$ атомном уровне

- Мир оптики и микроскопии

- Трехмерный интерактивный мир в химической электронной литературе

\section{Материалы для студентов и аспирантов}

- М.В.Ломоносов - основатель МГУ

- Книги, учебники, аналитические обзоры и статьи

- Лекции, учебно-методические материалы

- Неорганическая химия

- Органическая химия

Физическая химия

Кристаллохимия

Коллоидная химия

Аналитическая химия

Химия и фризика высоких давлений

Химическая технология

экологический риск

- Радиохимия

- Химия нефти и органического катализа

- Химическая кинетика

- Химия природных соединений

Химическая энзимология

- Химия высокомолекулярных соединений

- Список лекционных курсов для студентов Химического фрак-та МГУ

- Введение в историю и методологию химии.История химического факультета МГУ

- История и методология химии Философия

- Общая химия (для нехимических фракультетов)

- Химия для фризиков

- Математический анализ

- Материалы по социологии

- Правила оформления дипломных работ и подготовки документов к защите

- Программирование и решение задач на ЭВМ

- учебные базы данных

- Учебные материалы региональных университетов
○ Иркутский государственный университет
- Красноярский государственный университет 
Висновки. Виходячи 3 результатів дослідження стану розробок НКП, поінформованості та розповсюдженню їх серед навчальних закладів освіти, слід зазначити таке:

- багато вітчизняних розробок мають недостатній рівень якості та відповідності вимогам державної науково-технічної експертизи 3 питань присвоєння грифу МОН України, що потребує заснування Експертної ради 3 усіх ключових питань проходження та розробок таких програм від реєстрації, апробації до права на отримання Грифу сертифікації МОНУ;

- потрібно особливу увагу приділити розробці комп'ютерних програм для вивчення української мови та літератури, іноземних мов, а також економіки і права України, педагогічних програмних засобів, як використання системи тестування, проведення практикумів та дослідів у зручній для користувача формі, підтримку роботи у локальних мережах та мережі Інтернет, можливість дистанційного оновлення таких програм;

- недостатня поінформованість навчальних закладів актуальними та якісними розробками потребує єдиного централізованого Фонду навчальних комп'ютерних програм, електронних посібників та інноваційних розробок;

- доцільно використовувати досвід Російської Федерації у питаннях розробок НКП та комп’ютерних засобів навчання (КЗН), сертифікації, організації питання поінформованості та розповсюдженню їх в освітніх закладах.

Дослідження показали, щоб отримати високоякісну продукцію НКП, слід ще на стадії розробки проекту та підбору творчого колективу, включати високо компетентних та кваліфікованих спеціалістів: педагогів та психологів ... - на стадії проектування розробок та оцінювання продукції; кваліфікованих програмістів - на стадії реалізації проекту; а на стадії апробації, впровадження у використання та врахування зауважень - вчителів-користувачів.

Як показали дослідження, для перспективи подальшого поліпшення у питаннях поінформованості та розповсюдження нових надходжень розробок НКП, слід докорінно змінити підхід у вирішенні цієї проблеми. На позитивному прикладі досвіду РФ такі питання повинні вирішуватися на високому державному рівні та мати єдине джерело - Центральний Фонд навчальних комп'ютерних програм та інноваційних розробок. Тільки за широкої доступності до такого Фонду та простоти 
отримання високоякісної продукції можна очікувати підвищення якості та ефективності результатів впровадження НКП в системі освіти.

\section{Список використаних джерел}

1. Даниленко Л. І. Управління інноваційною діяльністю в загальноосвітніх закладах./Л. І. Даниленко : Монографія. - К.: Міленіум, 2004.- 358 с.

2. Ващеекко Л. М. Управління інноваційними процесами в загальній середній освіті регіону /Л. М. Ващенко : Монографія - К., 2005. - 380 с. - ВПЦ "Тираж ".

3. Гуржій A. М. Моделі та засоби розробки програмного та інформаційного забезпечення 3 навчальних предметів для загальноосвітніх навчальних закладів. [Електронний ресурс]. / Гуржій А.М., Гапон В.В.: Тези - Головний інформаційнообчислювальний центр Міністерства освіти і науки України. - Режим доступу: http://edu.ukrsat.com/labconf/tezy/8/modelsmethods.html - Заголовок з екрану.

4. Притуляк К. А. Аналіз тенденцій розвитку сучасних педагогічних програмних засобів навчання в умовах інформатизації навчально-виховних процесів. [Електронний ресурс] : [сайт Острів знань. Аналіз тенденцій розвитку сучасних ППЗ] / $\mathrm{K}$ А. Притуляк. - - Режим доступу: http://ostriv.in.ua/index.php?option=com_content\&task=view\&id=649\&Itemid=1067.\%20. - Заголовок з екрану.

5. Положення про проведення апробації електронних засобів навчального призначення / Міністерство освіти і науки України (МОН). Наказ № 433 від 02.06.2004 за N 757/9356 - Офіц.. вид. К. Законодавство України. / Про проведення апробації електронних засобів навчального призначення у загальноосвітніх, професійно-технічних, вищих педагогічних навчальних закладах та інститутах післядипломної освіти педагогічних кадрів у 2007/2008 навчальному році , від 03.10.2007 p. № 868

6. Сайт Острів знань. [Електронний ресурс]. - Режим доступу: http://ostriv.in.ua/index.php?option=com_menufolder\&Itemid=49 - Заголовок $з$ екрану.

7. Сайт для управлінців, психологів та педагогічних працівників автора комп'ютерних програм "Універсал" та ін. [Електронний ресурс]. - Режим доступу: http://www.unv.com.ua/. - Заголовок з екрану. 
8. Сайт Діагностично-проектуючого комп'ютерного комплексу Універсал. Банк файлів Універсал. [Електронний ресурс]. - Освітня система - Режим доступу: http://www.universal.modus.net.ua/baza.htm\#2. - Заголовок з екрану.

9. Сайт компанії “Дієз-продукт”. - Програми для керування закладами освіти [Електронний ресурс]. - Перелік електронних засобів навчального i загального призначення product.com.ua/index.php?go=Content\&id=41. - Заголовок з екрану.

10. Захлюпаний В. М.. Впровадження інформаційних технологій у діяльності закладу освіти. [Електронний ресурс]. / В. М. Захлюпаний. Організація та зміст діяльності наукових лабораторій інституту: - Науково-методичний посібник за ред. Н.І.Клокар, О.В.Чубарук., Біла Церква - 2005. - 260с. - Режим доступу: http://www.school13.pp.net.ua/publ/1-1-0-. - Заголовок з екрану.

11. Савченко 3. В. Основні вимоги до навчальних комп'ютерних програм в базовій середній освіті. [Електронний ресурс] / 3. В. Савченко. - Інформаційні технології і засоби навчання. Електронне наукове фахове видання, - 2008. - №3.Режим доступу: http://www.nbuv.gov.ua/e-journals/ITZN/em7/emg.html. - Заголовок 3 екрану.

12. Балыкина Е. Н. Слагаемые эффективности педагогических программных средств учебного назначения по историческим дисциплинам [Електронний ресурс]. / Е .Н Балыкина. Педагогическая эффективность обучающих программ - Режим доступу: http://www.informika.ru/text/magaz/comprog/n1-20/n1s13-36.html. - Заголовок з екрану.

13. Положение о статусе учебно компьютерных программ. / Информационные технологии и образование. Российский фонд компьютерных учебных программ - РОСФОКОМП., М. - 1997.

14. Электронная библиотека учебных материалов по химии. [Електронний pecypc]. / Электронная библиотека сайта "Chemnet" - Материалы для средней школы и абитуриентов. - Режим доступу: http://www.chem.msu.su/rus/elibrary/ - Заголовок 3 экрану.

\section{СОСТОЯНИЕ РАЗРАБОТОК ПРОГРАММНОГО ОБЕСПЕЧЕНИЯ И ИНФОРМАЦИОННЫХ БАЗ ДАННЫХ ДЛЯ УЧЕБНЫХ ЗАВЕДЕНИЙ}

Савченко 3.В. 


\section{Аннотация}

Статья посвящена актуальным вопросам современного состояния разработок компьютерных средств обучения и информационных баз данных учебнопедагогических компьютерных программ, способам информирования и распространения их в учебных заведениях, а также освещение опыта разработок Российской Федерации в аналогичных вопросах.

Ключевые слова: информационные базы данных, компьютерные программные средства обучения, общеобразовательное учебное заведение.

\section{CONDITION OF SOFTWARE AND INFORMATION DATABASES DEVELOPMENTS FOR EDUCATIONAL INSTITUTIONS}

\section{Savchenko Z.V.}

\section{Resume}

The paper is devoted to up-to-date questions concerning the modern condition of development of computer means of training and information databases of educationpedagogical computer programs, the ways of their informing and distribution into educational institutions, as well as presentation of the experience on similar developments in the Russian Federation.

Keywords: information databases, computer software of training, secondary educational institution. 